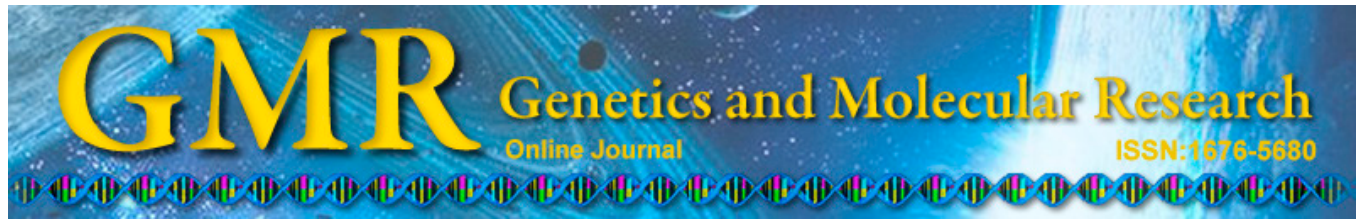

\title{
Backcrossing to increase meiotic stability in triticale
}

\author{
R.M. Giacomin ${ }^{1}$, R. Assis ${ }^{2}$, S.P. Brammer ${ }^{3}$, A. Nascimento Junior ${ }^{3}$ and \\ P.R. Da-Silva ${ }^{1,2}$ \\ ${ }^{1}$ Programa de Pós-Graduação em Biologia Evolutiva, \\ Universidade Estadual do Centro-Oeste, UNICENTRO, \\ Guarapuava, PR, Brasil \\ ${ }^{2}$ Laboratório de Genética e Biologia Molecular Vegetal, \\ Departamento de Ciências Biológicas, UNICENTRO, \\ Guarapuava, PR, Brasil \\ ${ }^{3}$ Empresa Brasileira de Pesquisa Agropecuária, \\ Centro Nacional de Pesquisa de Trigo, Embrapa-Trigo, \\ Passo Fundo, RS, Brasil \\ Corresponding author: P.R. Da-Silva \\ E-mail: prsilva@unicentro.br
}

Genet. Mol. Res. 14 (3): 11271-11280 (2015)

Received February 19, 2015

Accepted May 29, 2015

Published September 22, 2015

DOI http://dx.doi.org/10.4238/2015.September.22.21

ABSTRACT. Triticale (X Triticosecale Wittmack) is an intergeneric
hybrid derived from a cross between wheat and rye. As a newly created
allopolyploid, the plant shows instabilities during the meiotic process,
which may result in the loss of fertility. This genomic instability
has hindered the success of triticale-breeding programs. Therefore,
strategies should be developed to obtain stable triticale lines for
use in breeding. In some species, backcrossing has been effective
in increasing the meiotic stability of lineages. To assess whether
backcrossing has the same effect in triticale, indices of meiotic
abnormalities, meiotic index, and pollen viability were determined
in genotypes from multiple generations of triticale $\left(\mathrm{P}_{1}, \mathrm{P}_{2}, \mathrm{~F}_{1}, \mathrm{~F}_{2}\right.$,
$\mathrm{BC}_{1 \mathrm{a}}$, and $\left.\mathrm{BC}_{1 \mathrm{~b}}\right)$. All analyzed genotypes exhibited instability during 
meiosis, and their meiotic index values were all lower than normal. However, the backcrosses $\mathrm{BC}_{1 \mathrm{a}}$ and $\mathrm{BC}_{1 \mathrm{~b}}$ showed the lowest mean meiotic abnormalities and the highest meiotic indices, demonstrating higher stability. All genotypes showed a high rate of pollen viability, with the backcrosses $\mathrm{BC}_{1 \mathrm{a}}$ and $\mathrm{BC}_{1 \mathrm{~b}}$ again exhibiting the best values. Statistical analyses confirmed that backcrossing positively affects the meiotic stability of triticale. Our results show that backcrossing should be considered by breeders aiming to obtain triticale lines with improved genomic stability.

Key words: X Triticosecale Wittmack; Meiosis; Pollen viability; Plant breeding; Cytogenetics

\section{INTRODUCTION}

Triticale (X Triticosecale Wittmack) represents the first hybrid resulting from an artificial cross between two species of different genera, whereby wheat (Triticum spp) is the male parent and rye (Secale cereale) is the female parent. This artificial hybrid succeeded in combining key attributes of the two parental species, which are the high productivity and energy value of wheat and the resistance to environmental stresses and elevated protein level of rye (Oetller, 2005). Triticale is primarily self-pollinated, although it may undergo some cross-pollination (Oettler et al., 1991; Lelley, 1992).

Polyploidy is an evolutionary process that has the greatest effect in plants, and represents a major mechanism of speciation (Ramsey and Schemske, 1998). Approximately $80 \%$ of angiosperm species are polyploid, indicating the importance of this mechanism for genetic development and the evolutionary implications of polyploidy as an important source of genetic variability (Leitch and Bennett, 1997). Triticale is an allopolyploid originating from the hybridization of two different species. Although many cultivated allopolyploids are fertile, adapted, and genetically stable, recent, natural, or artificial polyploids may exhibit high meiotic instability, sterility, and a high frequency of aneuploids in their progeny (Leitch and Bennett, 1997; Ramsey and Schemske, 1998).

Among the disorders presented by allopolyploid species are meiotic and mitotic instability, differences in parental cell cycle length, and low pollen fertility (Thomas and Kaltsikes, 1971). Cytogenetic analysis has been used to identify and resolve these disorders in several crop species. The focus of cytogenetic analyses in breeding is to determine whether these abnormalities alter the fertility, and thus the productivity, of the plant (Hayes et al., 1955). In triticale, all of these previously mentioned meiotic disorders have been observed, and have negative consequences on breeding (Guerra et al., 2011). It is therefore essential to identify methodologies for triticale-breeding programs through which plants with meiotic stability might be obtained.

Several studies have reported improvements in the number of normal cells during meiosis when segregating genotypes are crossed with their parents (Hauser et al., 1998; Guo et al., 2010). However, these studies have been conducted and confirmed in relatively few species. Thus, because triticale plants experience serious problems during meiosis, this species can be used to test this hypothesis.

To test the hypothesis that backcrossing can improve indices of normalcy during 
meiosis in triticale, the present study examined meiotic behavior, pollen viability, and meiotic stability in the triticale cultivars 'Embrapa 53' and 'BRS Minotauro' from $\mathrm{F}_{1}$ and $\mathrm{F}_{2}$ generations and $\mathrm{BC}_{1 \mathrm{a}}$ and $\mathrm{BC}_{1 \mathrm{~b}}$ backcrosses. After surveying these data, the results were evaluated using statistical tests to verify whether backcrossing positively influenced meiotic stability in triticale.

\section{MATERIAL AND METHODS}

\section{Genotypes and crosses}

In this study, six different genotypes were examined: the parental cultivars 'Embrapa 53' and 'BRS Minotauro', $\mathrm{F}_{1}$ and $\mathrm{F}_{2}$ generations, and $\mathrm{BC}_{1 \mathrm{a}}$ and $\mathrm{BC}_{1 \mathrm{~b}}$ backcrosses.

To obtain segregating generations, 'Embrapa 53' was used as the male parent and 'BRS Minotauro' as the female parent. This cross produced the $F_{1}$ generation. Selfing the $F_{1}$ generation plants produced the $\mathrm{F}_{2}$ generation.

$\mathrm{F}_{1}$ plants were crossed with 'Embrapa 53' and 'BRS Minotauro' to obtain the $\mathrm{BC}_{1 \mathrm{a}}$ and $\mathrm{BC}_{1 b}$ generations, respectively. All crosses described in this study were performed at the Brazilian Wheat Researcher Center (EMBRAPA Trigo) in Passo Fundo county, RS, Brazil $\left(28^{\circ} 15^{\prime} 40^{\prime \prime} \mathrm{S}, 52^{\circ} 24^{\prime} 30^{\prime \prime} \mathrm{W}\right)$.

\section{Cytogenetic analyses}

To collect plant material for cytogenetic analysis, the different triticale genotypes were planted in an experimental field located in Guarapuava county, PR, Brazil $\left(25^{\circ} 23^{\prime} 43^{\prime \prime} \mathrm{S}, 51^{\circ} 27^{\prime} 29^{\prime \prime} \mathrm{W}\right)$. Spikelets were collected at different stages of development to ensure that all meiotic phases were sampled. For pollen viability and cytogenetic analysis, the collected spikelets were fixed in Carnoy's solution (absolute ethanol/acetic acid, $3: 1, \mathrm{v} / \mathrm{v}$ ) and stored in labeled plastic containers. The collected material was kept in Carnoy's solution at room temperature for $24 \mathrm{~h}$. After this process, the spikelets were washed three times with $70 \%$ ethanol and stored in $70 \%$ ethanol at $-20^{\circ} \mathrm{C}$ until slides were prepared.

The slides were prepared by the squashing technique. Anthers were isolated, cut, and pressed transversely to release the cells. The slides were then stained with $1 \%$ propionic carmine, heated under a flame, and squashed.

Six plants of each genotype ('Embrapa 53', 'BRS Minotauro', $\mathrm{F}_{1}, \mathrm{~F}_{2}, \mathrm{BC}_{1 \mathrm{a}}$, and $\mathrm{BC}_{1 \mathrm{~b}}$ ) were analyzed, making a total of 36 plants. Six hundred cells were analyzed for each genotype, consisting of 100 cells from each meiotic stage (metaphase I to tetrad). All abnormalities were considered, and the most representative were photographed. The meiotic index (MI) was calculated according to the method described by Love (1949) using the following formula: number of normal tetrads divided by total number of tetrads $\mathrm{x} 100$.

The slides used to analyze pollen viability were produced using three anthers of the same flower collected from the middle region of the spike. The squashing technique was also used to prepare these slides, and the only difference was that $1 \%$ acetic carmine was used as the dye, which is considered more appropriate for the study of cereal pollen fertility. Six plants were 
analyzed for each genotype, and one slide was prepared from each plant. One thousand pollen grains were analyzed per slide, and the intensity of staining was used to determine viability such that infertile grains were empty and colorless, while fertile grains were a deep red color.

\section{Statistical analyses}

The results were submitted to analysis of variance (ANOVA) in SPSS (version 19.0 Inc., Chicago, IL, USA), and means were compared by Tukey and Fisher tests with a significance level of $5 \%(\mathrm{P}<0.05)$.

The results from the analysis of meiotic behavior were submitted to the Fisher variation test. Results with $\mathrm{P}<0.05$ were considered to be statistically different.

The data from the analyses of pollen viability were submitted to the Tukey test to identify the genotypes that were most viable.

\section{RESULTS}

\section{Meiotic behavior}

Different abnormalities were observed during meiosis from the early stages until the formation of pollen grains (Figure 1). The most common abnormalities were: precocious chromosome migration in metaphase I (Figure 1a and b); presence of laggard chromosomes and chromosome bridges in anaphase I (Figure 1c and d); micronuclei in telophase I (Figure 1e); chromosome stickiness in prophase II (Figure 1f and g); precocious chromosome migration in metaphase II (Figure 1h); laggard chromosomes in anaphase II (Figure 1i, j, and k), and micronuclei in tetrads (Figure 11). These abnormalities were observed in all of the genotypes analyzed.

The rate of observed abnormalities during the different meiotic phases in the parents and in the segregating generations of triticale ranged from 5 to $85 \%$ (Table 1). The parents 'Embrapa 53' and 'BRS Minotauro' had the highest rates of abnormalities. The $\mathrm{F}_{2}$ generation had an intermediate rate of abnormalities (Table 1), while the backcrosses $\mathrm{BC}_{1 \mathrm{a}}$ and $\mathrm{BC}_{1 \mathrm{~b}}$ showed the lowest levels of cellular abnormalities (Table 1).

The rate of abnormalities was considered high for most of the meiotic phases analyzed and was most significant in the phases of meiosis I. The mean rate of abnormalities decreased in all genotypes during the phases of meiosis I, declining from $73 \%$ in metaphase I to $18 \%$ in telophase I. Meiosis II began with a low mean rate of abnormalities, $14 \%$ in prophase II, which increased to $30 \%$ in anaphase II and decreased again at the end of division to $14 \%$ in telophase II (Table 1). The highest rate of abnormalities was observed in metaphase I in all genotypes (Table 1). As in the other phases of meiosis, high rates of abnormalities were observed in the tetrads, with 'Embrapa 53' and $\mathrm{BC}_{1 \mathrm{~b}}$ presenting the highest and lowest percentages of abnormality, respectively (Table 1 and Figure 2). The MI values ranged from 57 to $78 \%$ (Table 1), with the lowest value observed for 'Embrapa 53' and the highest for $\mathrm{BC}_{16}$ '.

ANOVA performed with the data obtained from the analysis of meiotic behavior revealed significant differences between the genotypes analyzed $(\mathrm{P}<0.05)$. The parents 'Embrapa 53' and 'BRS Minotauro' showed the greatest statistical distance from the other genotypes, with mean $P$ values being higher than 0.5 (Table 2). These results confirm that the parents were more unstable than subsequent generations in terms of meiotic abnormalities. 


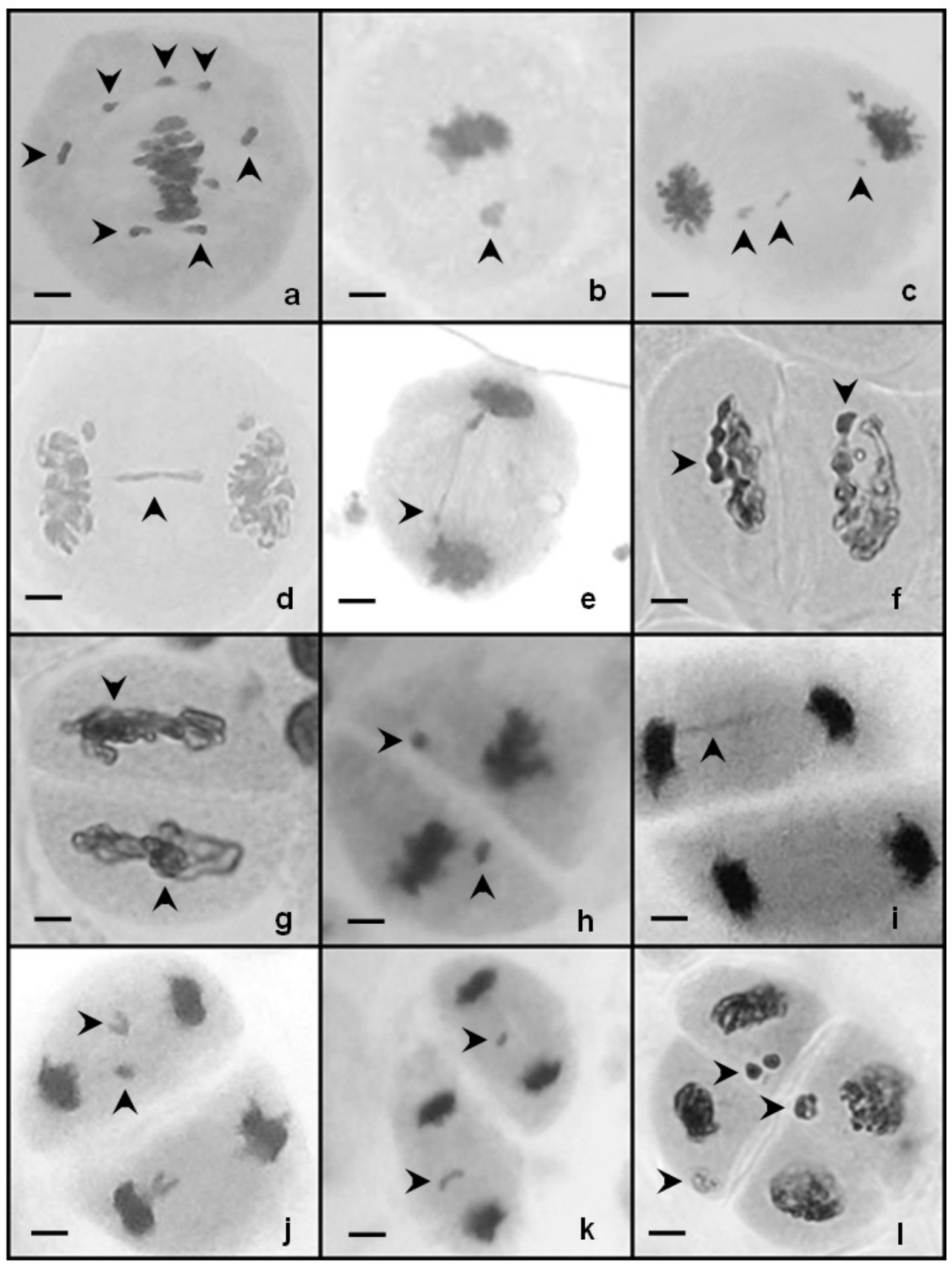

Figure 1. Abnormalities observed in the evaluated triticale genotypes. a. b. Metaphase I with precocious chromosomes; c. anaphase I with laggard chromosomes; d. telophase I with chromosomal bridges; e. anaphase I with chromosomal bridges; f. g. prophase II with chromosome stickiness; h. metaphase II with precocious chromosomes; i. j. k. anaphase II with laggard chromosomes; l. tetrad with micronuclei. Bar $=5 \mu \mathrm{m}$. 


\begin{tabular}{|c|c|c|c|c|c|c|c|c|c|}
\hline \multirow[t]{2}{*}{ Genotypes } & \multicolumn{3}{|c|}{ Meiosis I } & \multicolumn{4}{|c|}{ Meiosis II } & \multirow[t]{2}{*}{ Tetrad } & \multirow[t]{2}{*}{$\mathrm{Ml}$} \\
\hline & Met I & Ana I & Tel I & Pro II & Met II & Ana II & Tel II & & \\
\hline Embrapa 53 & 85 & 43 & 25 & 8 & 20 & 44 & 16 & 42 & 57 \\
\hline BRS Minotauro & 68 & 37 & 18 & 19 & 23 & 39 & 17 & 31 & 69 \\
\hline $\mathrm{F}_{1}$ & 65 & 35 & 16 & 20 & 17 & 22 & 11 & 28 & 72 \\
\hline $\mathrm{F}_{2}$ & 85 & 23 & 12 & 17 & 16 & 23 & 20 & 37 & 63 \\
\hline $\mathrm{B}^{2} \mathrm{C}_{1 \mathrm{a}}$ & 63 & 12 & 18 & 18 & 5 & 21 & 8 & 27 & 72 \\
\hline $\mathrm{BC}_{1 \mathrm{~b}}^{\mathrm{la}}$ & 72 & 18 & 20 & 5 & 28 & 32 & 15 & 22 & 78 \\
\hline Mean & 73 & 26 & 18 & 14 & 18 & 30 & 14 & 31 & \\
\hline
\end{tabular}

Met = metaphase $;$ Ana = anaphase $;$ Tel = telophase; Pro = prophase MI = meiotic index.

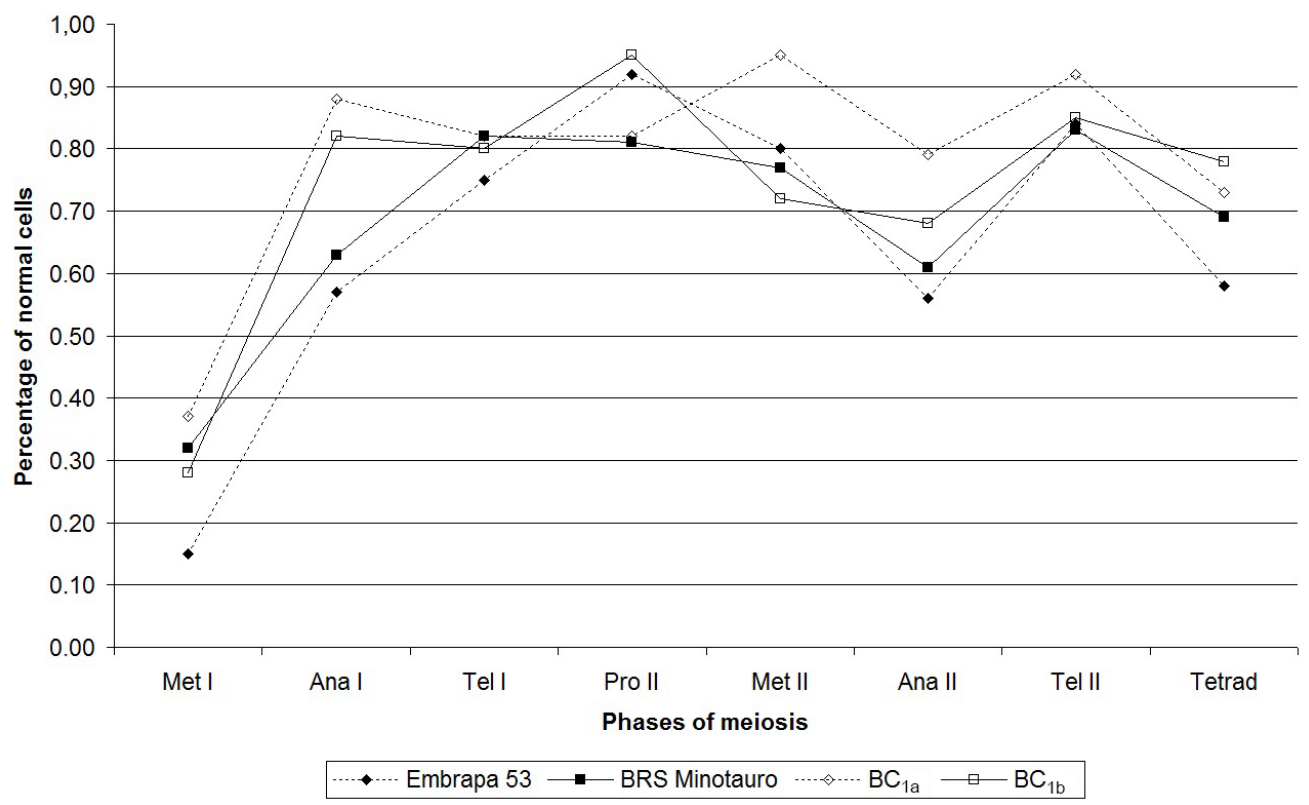

Figure 2. Percentage of normal cells observed during the phases of meiosis in the triticale genotypes 'Embrapa 53' and 'BRS Minotauro' (parents) and $\mathrm{BC}_{1 \mathrm{a}}$ and $\mathrm{BC}_{1 \mathrm{~b}}$ (backcrosses). $\mathrm{BC}_{1 \mathrm{a}}$ and $\mathrm{BC}_{1 \mathrm{~b}}$ originated from crosses of the $\mathrm{F}_{1}$ with 'Embrapa 53' and 'BRS Minotauro', respectively. For abbreviations, see Table 1.

Table 2. Percentages of viable pollen and the Fisher test of meiotic abnormalities in the triticale genotypes evaluated.

\begin{tabular}{lcc}
\hline Genotype & Mean viable pollen $(\%)^{*}$ & Mean P value for meiotic abnormalities** \\
\hline BRS Minotauro & $94^{\mathrm{b}}$ & 0.0780 \\
Embrapa 53 & $95^{\mathrm{b}}$ & 0.1400 \\
$\mathrm{~F}_{1}$ & $91^{\mathrm{b}}$ & 0.0220 \\
$\mathrm{~F}_{2}$ & $90^{\mathrm{b}}$ & 0.0470 \\
$\mathrm{BC}_{\mathrm{la}}$ & $93^{\mathrm{a}, \mathrm{b}}$ & 0.0012 \\
$\mathrm{BC}_{1 \mathrm{~b}}$ & $97^{\mathrm{a}}$ & 0.0130 \\
\hline
\end{tabular}

*Tukey test was used for pollen viability. Means followed by the same letter do not differ statistically at $\mathrm{P}<0.05$.

**Fisher test was used for analysis of meiotic abnormalities. 


\section{Pollen viability}

The mean percentage of viable pollen grains in the triticale genotypes analyzed ranged from 90 to $97 \%$ (Table 2). The $\mathrm{F}_{2}$ generation, although exhibiting the lowest rate of abnormalities during meiosis (Table 1), presented the lowest pollen viability (90\%). In contrast, 'Embrapa 53', which showed the highest rate of abnormalities during meiosis (Table 1 ), exhibited a pollen fertility rate of $94 \%$. The $\mathrm{BC}_{1 \mathrm{~b}}$ backcross showed the highest rate of pollen fertility (97\%) (Table 2). ANOVA and the Tukey test revealed significant differences between $\mathrm{BC}_{1 \mathrm{~b}}$ and the parental, $\mathrm{F}_{1}$, and $\mathrm{F}_{2}$ generations (Table 2).

\section{DISCUSSION}

\section{Meiotic behavior}

Analysis of triticale genotypes showed that the most common abnormality related to the irregular segregation of chromosomes was the presence of univalent chromosomes. The presence of univalents in the early stages of meiosis can influence the viability of meiotic products, because these chromosomes fail to remain aligned on the metaphase plate during metaphase and are thus conditioned to undergo early or late migration to the poles (Figure $1 \mathrm{a}$ and $\mathrm{b}$ ). This abnormality may cause the development of micronuclei in the next stages of meiosis, with aneuploid gametes forming at the end of division (Sybenga, 1992). Chiasmata are responsible for maintaining bivalent attachment until the anaphase stage. The early or late termination of these chiasmata, or even the absence of their formation, can lead to high rates of univalents, as observed in the present study (Baptista-Giacomelli et al., 2000a).

Several factors have been identified that affect the formation of chiasmata, of which asynaptic and desynaptic mutations are the most common; these errors are caused by mutations in genes that control chromosome pairing (Gupta and Priyadarshan, 1982). However, when some of these mutations occur, the resulting rate of univalents is very high, which has an impact on most of the bivalents (Calisto et al., 2008; Pagliarini et al., 2011), which was not observed in this study. Additionally, no asynaptic or desynaptic mutants have previously been described in triticale. The major cause of this abnormality may have been the temporal difference in the cell cycles of wheat and rye, the parental species of triticale. Because the plant is a hybrid generated by crossing two species of different genera, asynchrony may occur in the meiotic rhythms of the two genomes. This behavior is displayed in different natural amphidiploids such as Paspalum subciliatum (Adamowski et al., 2008), Brachiaria sp (Risso-Pascotto et al., 2002), and Brachiaria brizantha (Mendes-Bonato et al., 2002). These authors found that one of the parental genomes remained isolated at the equatorial plate throughout meiosis.

In triticale cells, the rapid cell cycle of rye may result in insufficient time for chiasmata formation in the chromosomes of wheat (Bennett, 1977). This hypothesis was first suggested with regard to triticale hexaploids by Tsuchiya (1970) and to octoploids by Pieritz (1970). Sisodia and McGinnis (1970) suggested that the formation of univalents is affected by cytoplasmic interactions. However, Merker (1973) and Tsunewaki et al. (1984) conducted studies in hexaploid triticale, and found no significant effects of the cytoplasm in these hybrids. Environmental factors may also influence the rate of chiasmata formation, and consequently the presence of univalents. In studies by Bodanese-Zanettini (1993) and Moraes-Fernandes (1982) using wheat, extremes of temperature and humidity decreased the frequency of chiasmata. 
Chromosomal stickiness is an abnormality unrelated to irregular segregation, and it is characterized by chromatin agglomeration (Pagliarini, 2000). Chromosomal gripping is common in plants and has been visualized in varieties of soybean (Bione et al., 2003) and oat (Baptista-Giacomelli et al., 2000b), among other species. Although a high frequency of cells with chromosome stickiness was observed in the present study, stickiness did not occur in all chromosomes in most of these cells. These abnormalities may be associated with environmental factors and soil composition, but it is currently impossible to identify the determining factor.

Pagliarini (2000) stated that the environmental conditions to which genotypes are subjected strongly influences the rate of chromosomal abnormalities. In wheat genotypes, Zanella et al. (1988) found that an excess of soil aluminum influences cell division. BodaneseZanettini et al. (1993) also demonstrated that higher temperatures lead to increased univalent frequency in dividing wheat cells, and induce different types of chromosomal abnormalities (including stickiness). This abnormality is commonly found in plants such as maize (CaetanoPereira et al., 1995), canola (Souza and Pagliarini, 1996), Centella asiatica (Consolaro and Pagliarini, 1996), and Brachiaria sp (Mendes-Bonato et al., 2001), among other species. In triticale, chromosome stickiness and associations can be attributed to the presence of rye chromosomes, which were indicated as a factor involved in the development of irregularities by Jung et al. (1985), Lelley (1992), and by Varghese and Lelley (1983).

\section{Meiotic index and pollen viability}

All genotypes showed mean MI values much lower than $90 \%$, which was proposed as the optimal level by Love (1949). The highest MI value was observed for $\mathrm{BC}_{1 \mathrm{~b}}(78 \%)$, while the lowest was observed for 'Embrapa 53' (57\%). These results are consistent with the analysis of meiotic phases, which demonstrated high instability in 'Embrapa 53'.

High levels of micronuclei were observed in the cells of all genotypes analyzed, but the mean numbers of normal tetrads found in the backcross generations were higher than those in other generations. These results indicate that backcrossing decreases the rate of abnormalities. As seen in the present study, crossing a partially stable $F_{1}$ plant with a partially stable parental plant yielded a generation with a lower rate of meiotic abnormalities than the parental generation (Figure 2). This difference was particularly prevalent for the backcross $\mathrm{BC}_{1 \mathrm{~b}}$, which was a cross between the parent 'BRS Minotauro' and the $\mathrm{F}_{1}$. The result of this cross $\left(\mathrm{BC}_{1 \mathrm{~b}}\right.$ ) presented 15\% more normal cells than 'BRS Minotauro' (Figure 2). The cross of $\mathrm{F}_{2}$ with 'Embrapa 53' (resulting in $\mathrm{BC}_{1 \mathrm{a}}$ ) also presented 9\% more normal cells than 'Embrapa 53'. Similar results to those of the present study have been described regarding backcrosses in Brassica sp (Hauser et al., 1998), as well as in Solanum tuberosum and Solanum chacoense (Guo et al., 2010). Considered together, these results indicate that genomic stability in triticale may be improved by performing crosses between more stable lines and their respective parents.

Our results demonstrate that, despite the constant process of selection and breeding in triticale, many meiotic irregularities still occur and can lead to low fertility. In this regard, because triticale is a newly created allopolyploid, more time is required for the evolution of stable meiosis in this species (Leitch and Bennett, 1997). Given this scenario, cytogenetics can support the selection of more stable genotypes for crosses and backcrosses in triticale-breeding programs.

In this study, pollen viability was high in both triticale parents analyzed. This indicates that meiotic behavior was not the sole influence on the viability of pollen grains. 
When comparing the MI values of the genotypes, no relationship was observed between the percentage of normal tetrads and the percentage of viable pollen grains. These data show that pollen viability does not always represent the reproductive capacity of the plant, as viable pollen grains may not always be capable of germination. This occurs because some meiotic abnormalities only have an effect during the germination stage and do not influence pollen viability (Junqueira Filho et al., 2003). Similar results have been reported for other genotypes of hexaploid triticale (Rosa et al., 2006; Zanotto et al., 2009).

The observation that subsequent generations of reciprocal crosses in triticale show reduced meiotic abnormalities (as seen in backcross $\mathrm{BC}_{1 \mathrm{a}}$ and $\mathrm{BC}_{1 \mathrm{~b}}$ ) is unprecedented for this species. This result may open new perspectives for triticale-breeding programs. The present results confirm that cytogenetic study is an excellent tool for measuring heritable male reproductive capacity and that it should be considered as an indicator of the degree of stability and productivity of triticale lines. Thus, it is possible to infer that plant breeding associated with cytogenetics will be successful in decreasing the rate of meiotic abnormalities through selection. However, achieving complete meiotic stability for triticale remains a distant goal in light of the recent origin of the species.

\section{Conflicts of interest}

The authors declare no conflict of interest.

\section{REFERENCES}

Adamowski EV, Pagliarini MS and do Valle CB (2008). Meiotic behaviour in three interspecific three-way hybrids between Brachiaria ruziziensis and B. brizantha (Poaceae: Paniceae). J. Genet. 87: 33-38.

Baptista-Giacomelli FR, Pagliarini MS and Almeida JL (2000a). Chiasma frequency, distribution and terminalization in hexaploid oats (Avena sativa L.). Acta Sci. 22: 269-273.

Baptista-Giacomelli FR, Pagliarini MS and Almeida JL (2000b). Elimination of micronuclei from microspores in a Brazilian oat (Avena sativa L.) variety. Genet. Mol. Biol. 23: 681-684.

Bennett MD (1977). Heterochromatin, aberrant endosperm nuclei and grain shriveling in wheat-rye genotypes. Heredity 39: 411-419.

Bione NCP, Pagliarini MS and Almeida LA (2003). Further cytological characteristics of a male-sterile mutant in soybean [Glycine $\max$ (L.) Merrill] affecting cytokinesis and microspore development. Plant Breed. 122: 244-247.

Bodanese-Zanettini MH, Zanella CC, Silvazary AM, Moraes-Fernandes MIB, et al. (1993). Aneuploidy and chromosome mosaics in hexaploid wheat (Triticum aestivum L. Thell.) cultivars. Cereal Res. Commun. 21: 269-275.

Caetano-Pereira CM, Pagliarini MS, Brasil CM and Martins EN (1995). Influence of aluminum in causing chromosome stickiness in maize microsporocytes. Maydica 40: 325-330.

Calisto V, Fuzinatto VA, Message HJ, Mendes-Bonato AB, et al. (2008). Desynapsis and precocious cytokinesis in Brachiaria humidicola (Poaceae) compromise meiotic division. J. Genet. 87: 27-31.

Consolaro MEL and Pagliarini MS (1996). Spontaneus chromosome stickiness in microsporocytes of Centella asiatica (L.) Urban (Umbelliferae). Cytologia 61: 57-61.

Guerra D, Pacheco MT and Federizzi LC (2011). Analysis of self-fertilization and meiotic behavior of eleven Brazilian triticale cultivars at two sowing dates. Crop Breed. Appl. Biotechnol. 11: 114-124.

Guo X, Xie C, Cai X, Song B, et al. (2010). Meiotic behavior of pollen mother cells in relation to ploidy level of somatic hybrids between Solanum tuberosum and S. chacoense. Plant Cell Rep. 29: 1277-1285.

Gupta PK and Priyadarshan PM (1982). Triticale: present status and future prospects. Adv. Genet. 21: 255-345.

Hauser TP, Jørgensen RB and Østergård H (1998). Fitness of backcross and F2 hybrids between weedy Brassica rapa and oilseed rape (B. napus). Heredity 81: 436-443.

Hayes KH, Immer FR and Smith CD (1955). Methods of Plant Breeding. 2nd edn. McGraw-Hill Publishing Co., London. Jung C, Lelley T and Röbbelen G (1985). Genetic interactions between wheat and rye genomes in triticale. Theor. Appl. 
Genet. 70: 422-426.

Junqueira-Filho RG, Mendes-Bonato AB, Pagliarini MS, Bione NC, et al. (2003). Absence of microspore polarity, synmetric divisions and pollen cell fate in Brachiaria decumbens (Gramineae). Genome 46: 83-88.

Leitch IJ and Bennett MD (1997). Polyploidy in angiosperms. Trends Plant Sci. 2: 470-476.

Lelley T (1992). Triticale, still a promise? Plant Breed. 109: 1-17.

Love RM (1949). La citología como ayuda práctica a mejoramiento de los cereales. Rev. Agron. Noroeste Argent. 16: 1-13.

Mendes-Bonato AB, Pagliarini MS, Valle CB and Penteado MIO (2001). A severe case of chromosome stickiness in pollen mother cells of Brachiaria brizantha (Hochst) Stapf (Gramineae). Cytologia 66: 287-291.

Mendes-Bonato AB, Junqueira Filho RG, Pagliarini MS, Borges Do Valle C, et al. (2002). Unusual cytological patterns of microsporogenesis in Brachiaria decumbens: abnormalities in spindle and defective cytokinesis causing precocious cellularization. Cell Biol. Int. 26: 641-646.

Merker A (1973). Cytogenetic investigations in hexaploid Triticale. Meiosis and fertility in F1 and F2. Hereditas 73: 285-289.

Moraes-Fernandes MIB (1982). Citogenética. In: Trigo no Brasil, (Osório EA, ed. Fundação Cargill, Campinas, 95-144.

Oetller G (2005). The fortune of a botanical curiosity - Triticale: past, present and future. J. Agric. Sci. 143: 329-346.

Oettler G, Wehmann F and Utz HF (1991). Influence of wheat and rye parents on agronomic characters in primary hexaploid and octoploid triticale. Theor. Appl. Genet. 81: 401-405.

Pagliarini MS (2000). Meiotic behavior of economically important plant species: the relationship between fertility and male sterility. Genet. Mol. Biol. 23: 997-1002.

Pagliarini MS, Souza VF, Silva N, Scapim CA, et al. (2011). ms17: a meiotic mutation causing partial male sterility in a corn silage hybrid. Genet. Mol. Res. 10: 1958-1962.

Pieritz WJ (1970). Elimination von Chromosomen in amphidiploiden Weizen-Roggen-Bastarden (Triticale). Zeitschrift Pflanzenzüchtung 64: 90-109.

Ramsey J and Schemske DW (1998). Pathways, mechanisms, and rates of polyploid formation in flowering plants. Annu. Rev. Ecol. Syst. 29: 467-501.

Risso-Pascotto C, Pagliarini MS and Valle CB (2002). Abnormal nucleolar cycle in microsporogenesis of Brachiaria decumbens (Gramineae). Cytologia 67: 355-360.

Rosa SP, Corrêa GSM, Nascimento Junior A, Brammer PS, et al. (2006). Análise de Tétrades e Grãos de Pólen em Triticale Hexaplóide. Available at [http://www.ufpel.edu.br/cic/2006/arquivos/CB_00895.rtf]. Accessed January 25, 2014.

Sisodia NS and McGinnis RC (1970). Importance of hexaploid wheat germplasm in hexaploid triticale breeding. Crop Sci. 10: 161-162.

Souza AM and Pagliarini MS (1996). Spontaneous chromosome stickiness in canola. Nucleus 39: 85-89.

Sybenga J (1992). Cytogenetics in plant breeding. 17th edn. Monographs on Theoretical and Applied Genetics, Berlin.

Thomas JB and Kaltsikes PJ (1971). Chromosome pairing in hexaploid triticale. Can. J. Gen. Cytol. 13: 621-624.

Tsuchiya T (1970). Chromosome pairing at diakinesis in hexaploid Triticale. eWis 31: 22-23.

Tsunewaki K, Iwanaga M, Maekawa M and Tsuji S (1984). Production and characterization of alloplasmic lines of a triticale 'Rosner'. Theor. Appl. Genet. 68: 169-177.

Varghese JP and Lelley T (1983). Origin of nuclear aberrations and seed shrivelling in triticale: a re-evaluation of the role of C-heterochromatin. Theor. Appl. Genet. 66: 159-167.

Zanella CC, Zanettini MHB, Moraes-Fernandes MI and Zinn DM (1988). Genotypic differences in chromosomal behaviour of wheat cultivars to soil acidity. Ann. Wheat Newslet. 34: 36-37.

Zanotto M, Brammer SP, Nascimento Junior A and Scargliusi SM (2009). Viabilidade polínica como seleção assistida no programa de melhoramento genético de triticale. Cienc. Agrotec. 33: 2078-2082. 